develop subsequent pulmonary and hepatic complications. Phenotype $\mathrm{P}_{\mathrm{i}} \mathrm{MZ}$ will produce intermediate values of $\alpha_{1}$-antitrypsin (approximately $50 \%$ ) which may be associated with liver disease. ${ }^{4}$ The $\mathrm{Z}$ band is observed to migrate cathodally to the $\mathrm{M}$ band.

In these two patients there was an abnormal protein migrating similar to that of the $\mathrm{Z}$ band during the acute phase of the hepatitis. This was incompatible with the parents' phenotypes and resolved during the recovery phase. This phenomenon has been seen once previously in neonatal hepatitis associated with cytomegalovirus infection. ${ }^{5}$ It may be caused by 'switching on' of the production of an abnormal protein during the acute phase of the illness, or to decreased post ribosomal sialylation of the normal $\mathrm{M}$ protein. This has yet to be clarified.

It is important to be aware of this transient abnormality, which may occur in neonatal hepatitis, and to check both parents' $\alpha_{1}$-antitrypsin phenotypes. This may avoid erroneous counselling in respect of the prognosis and the genetic implications.
I thank Dr K L Dodd, Consultant Paediatrician, Derby City Hospital for permission to discuss two of his patients and $\mathrm{Dr} A$ Milford-Ward, Director, Supraregional Protein Reference Unit, Sheffield for his helpful advice.

\begin{abstract}
References
${ }^{1}$ Nebbia G, Hadchouel M, Odievre M, Alagille D. Early assessment of evaluation of liver disease associated with $\alpha_{1}$-antitrypsin deficiency in childhood. J Pediatr 1983;102:661-5.

2 Sveger T. $\alpha_{1}$-Antitrypsin deficiency in early childhood. Pediatrics 1978;62:22-5.

${ }^{3}$ Tobin MJ, Cook PJL, Hutchinson DCS. Alpha ${ }_{1}$ antitrypsin deficiency: the clinical and physiological features of pulmonary emphysema in subjects homozygous for $\mathrm{P}_{\mathrm{i}}$ Type $\mathrm{Z}$. Br J Dis Chest 1983;77:14-27.

4 Tanner MS, Allen R, Milford-Ward A. Alpha ${ }_{1}$-antitrypsin deficiency and liver disease. Br Med $J$ 1983;283:1263.

5 Hug G., Chuck G, Bowles B. Alpha ${ }_{1}$-antitrypsin phenotype: transient cathodal shift in serum of infant girl with urinary cytomegalovirus and fatty liver. Pediatr Res 1982;16:192-8.
\end{abstract}

Correspondence to Dr A A Attenburrow, Department of Neonatal Medicine and Surgery, Nottingham City Hospital, Nottingham NG5 1PB.

Received 20 November 1984

\title{
Oxandrolone in low dose for constitutional delay of growth and puberty in boys
}

\author{
R STANHOPE AND C G D BROOK
}

Department of Paediatrics, Middlesex Hospital, London

\begin{abstract}
SUMmarY Twenty four boys with delayed pubertal growth spurt were treated with oxandrolone $(2.5 \mathrm{mg}$ daily) for 0.21 to 0.65 years. The mean increment of growth velocity was $4.4 \mathrm{~cm} /$ year during treatment, which was maintained at $3.7 \mathrm{~cm} /$ year after treatment. There was no significant change in height for bone age standard deviation scores.
\end{abstract}

Constitutional delay of growth occurs in otherwise healthy adolescents with stature reduced for chronological age but generally appropriate for bone age and the stage of pubertal development, both of which are usually delayed. There is often considerable delay in the onset of the puberty growth spurt which may cause severe psychological disturbance.

Oxandrolone $\left(17^{2}\right.$-hydroxy-17-methyl-2-oxa- $5^{2}$ androstan-3-one) is one of a group of anabolic steroids derived from testosterone which accelerate growth. ${ }^{1}$ Their use in the treatment of short stature has fallen into disrepute because of potential side effects. These include virilisation, suppression of the hypothalamic-pituitary axis, and hepatotoxicity but the most serious problem is the potential to advance bone age disproportionately to height gain, which compromises final adult height. The poor reputation that anabolic steroids have gained may partly be due to the large doses which were first used. ${ }^{1}$ Growth acceleration does not seem to be related to dose but advance in skeletal maturation is. ${ }^{1}$ We have attempted to define an effective treatment regimen, free of side effects, using oxandrolone.

\section{Patients and methods}

Twenty four, short, pubertal boys (testicular volumes more than $3 \mathrm{ml}$ ) were treated with oxandrolone because of severe psychological disturbance. Two had mild asthma and one had severe psoriasis which had been treated with topical fluorinated corticosteroids. The heights of all patients were less than the 3rd centile for chronological age, except for one, whose height was on the 10th centile. Fourteen had delayed puberty with testicular volumes less than the 10th centile for chronological age. ${ }^{2}$ Mean bone 
age retardation was 2.4 years. Oxandrolone was given in a dose of $2.5 \mathrm{mg}$ daily for three to four months to 21 patients and for six months in three patients: four patients received a second course of treatment because height velocity was not maintained in the period after treatment on the first occasion. One child was lost to follow up.

Heights were measured using a stadiometer and height velocities calculated for each preceding interval. Puberty ratings, testicular volumes, and skeletal maturation ${ }^{3}$ were assessed by the same observer (CGDB). Growth measurements have been expressed as standard deviation scores (SDS) to allow for varying means and standard deviations (SD) of normal values with age ${ }^{4}$ using the formula:

$$
\mathrm{SDS}=(\mathrm{X}-\overline{\mathrm{X}}) / \mathrm{S} \text {, }
$$

where $X$ is the measurement of the patient, $\bar{X}$ the population mean for chronological age and $S$ the standard deviation. Height SDS was related to bone age to determine adult height potential. Results were analysed by paired Student's $t$ tests.

\section{Results}

Oxandrolone increased height velocity from a mean of $3.7 \mathrm{~cm} /$ year to $8.1 \mathrm{~cm} /$ year $(P<0.001)$, and this high velocity was maintained at $7.4 \mathrm{~cm} /$ year after stopping treatment (Table). All patients had a normal progression of testicular volume and genital and pubic hair development during and after treatment. Mean testicular volume at the end of the treatment period was $9.3 \mathrm{ml}$. Although mean height for bone age SDS decreased from -0.64 to -0.9 , this change was small and not significant $(P>0 \cdot 1)$.
No side effects associated with oxandrolone were experienced during this study.

\section{Discussion}

Growth delay in adolescent boys is a common problem. When associated with delayed puberty it may be particularly distressing and cause deviant behaviour and severe psychological problems. These may interfere with education at a time when academic achievement is of life long importance and the deviant behaviour may be of such severity that it causes problems with the law (shoplifting, vandalism etc). Most of these boys do not require extensive endocrinological investigation but they do urgently need a treatment for their delay in growth that is free of side effects. All our patients had an improvement of their psychological disturbance following the oxandrolone induced growth acceleration.

Oxandrolone does not seem to advance skeletal maturity excessively, even in dosages of 2.5 to 10 $\mathrm{mg} /$ day for periods of up to two years. ${ }^{5}$ In pubertal boys we have found that as little as $2.5 \mathrm{mg}$ of oxandrolone daily for a period of three months has produced a highly significant growth acceleration, which persisted without a disproportionate advance in bone age. Even lower doses may be effective in this situation but this requires further study.

The mechanism by which oxandrolone brings its effect is probably by increasing growth hormone secretion. Many boys with a delayed growth spurt have a suppression of growth hormone secretion to the usual provocative stimuli which recovers when

Table Clinical data on pubertal boys treated with oxandrolone (pretreatment, treatment and post treatment periods were in continuity)

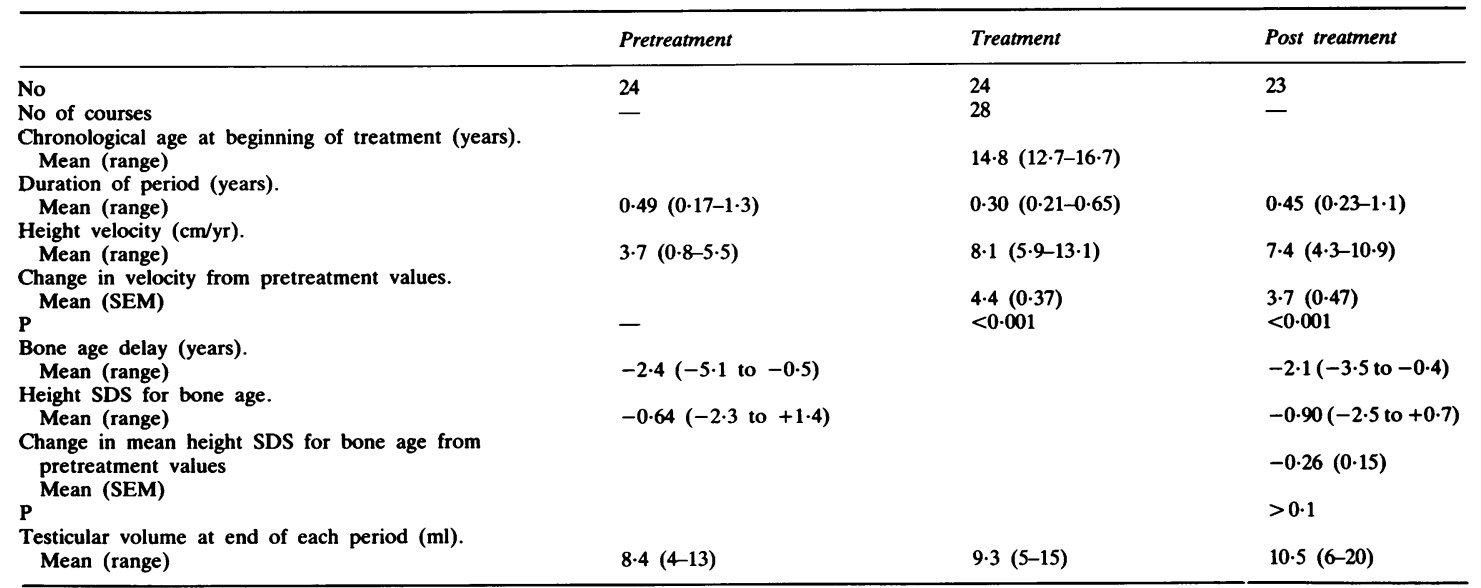


they enter puberty. ${ }^{6}$ Administration of testosterone before tests of growth hormone secretion are performed may separate those with temporary growth hormone deficiency from boys with true growth hormone deficiency, ${ }^{6}$ who are in any case much shorter than the patients we are treating. We have not, at present, investigated the mechanism of action of oxandrolone but it is clear that we are observing a definite effect of treatment. Boys with testicular volumes of less than $12 \mathrm{ml}$ do not suddenly double their growth velocity over a three month period. The triggering of a sustained growth spurt in individual cases is most impressive.

Oxandrolone has been available for the last two decades but it does not have a product licence in the United Kingdom. We submit that for the purposes we have defined, it would be an important addition to the therapeutic armamentarium.
References

1 Sobel EH. Anabolic steroids. In: Astwood EB, Cassidy CE, eds. Clinical endocrinology. Vol 2. New York: Grune and Stratton, 1968:789-97.

2 Zachmann M, Prader A, Kind HP, Hafliger $\mathbf{H}$, Budliger $\mathbf{H}$. Testicular volume during adolescence. Cross sectional and longitudinal studies. Helv Paediatr Acta 1974;29:61-72.

3 Tanner JM, Whitehouse RH, Marshall WA, Healey MJR, Goldstein H. Assessment of skeletal maturity and prediction of adult height. London: Academic Press, 1975.

4 Tanner JM, Whitehouse RH, Takaishi M. Standards from birth to maturity for height, height-velocity and weight-velocity: British children, 1965. Arch Dis Child 1966;41:613-35.

5 Kelly VC, Ruvalcaba RHA. Use of anabolic agents in treatment of short children. Clin Endocrinol Metab 1982;11:25-39.

6 Preece MA. Growth hormone deficiency. In: Brook CGD, ed. Clinical paediatric endocrinology. Oxford: Blackwell, 1981:294.

Correspondence to Dr C G D Brook, Department of Paediatrics, The Middlesex Hospital, Mortimer Street, London, W1N 8AA.

Received 2 November 1984

\section{Candida in mouth or on dummy?}

\section{J MANNING, R P COUGHLIN, AND E M E POSKITT}

\section{Alder Hey Children's Hospital, Liverpool; Royal Liverpool Children's Hospital; and Institute of Child} Health, University of Liverpool

SUMMARY Mouth and dummy swabs for Candida spp. were obtained from 100 children under 18 months old admitted with acute medical conditions. Forty four per cent of dummies were colonised by Candida spp. Children who sucked dummies had clinical thrush and positive mouth swabs for candida more frequently than those who did not.

Many infants use dummies routinely in the first years of life. Spence et $\mathrm{al}^{1}$ recorded the habit in $62 \%$ of 967 infants but felt this percentage was probably an underestimate. They were unable to show a relation between the use of dummies and infantile infection but the contribution of dummy sucking to childhood infection has been studied little. We have reviewed the relation between dummy sucking and the presence of a potential pathogenic candida in the mouths of young children.

\section{Methods}

A swab from the dorsum of the tongue and the inside of the cheeks was obtained from each of 100 children less than 18 months old admitted to the Royal Liverpool Children's Hospital with acute medical conditions. Dummies were sampled using swabs moistened with sterile saline. Mouth and dummy swabs were spread on Sabouraud's medium and incubated at $37^{\circ} \mathrm{C}$ for 24 to 48 hours. Colonies were identified as Candida albicans by Gram stain and a positive germ tube reaction. Germ tube negative strains were identified using the API-Zym system (API Products). Children were allowed to continue sucking their dummies if this was comforting. Further mouth and dummy swabs were obtained twice weekly during each child's admission.

\section{Results}

Sixty six children sucked a dummy regularly and 34 did not. There was no significant difference in age, sex, gestational age at birth, or method of feeding between those who sucked dummies and those who did not. Similarly, there was no social class difference between the two groups. Medical admissions to this hospital come predominantly from a deprived urban area with a high rate of unemployment.

Seven children had clinical oral thrush (all $C$ albicans). Six of these children sucked dummies and positive dummy cultures were obtained from all but one of this group.

Thirty six children who sucked dummies had 